\title{
NAUKA ENCYKLIKI „HUMANAE VITAE” O MIEOŚCI (analiza tekstu)
}

\section{WSTEP}

Encyklika Pawła VI Humanae vitae zawiera w sobie obszerne pouczenie na temat miłości małżeńskiej. Idzie ona $\mathrm{w}$ tym za orientacją, jaka wyraźnie się przejawiła na Soborze Watykańskim II, zarówno w dyskusjach, jak też w ostatecznej redakcji dokumentu Gaudium et spes - w drugiej części tego dokumentu zawiera się właśnie rozdział o małżeństwie i rodzinie. W dyskusji podnoszono niejednokrotnie potrzebę dowartościowania miłości jako celu małżeństwa w stosunku do prokreacji. Ujęcie problemów etycznych małżeństwa na gruncie miłości wydaje się bardzo właściwe i trafne przede wszystkim ze względów psychologicznych, odpowiada bowiem jakiejś podstawowej prawdzie życia ludzkiego. Równocześnie zaś wprowadza nas ona w tę dziedzinę moralności, która w pełni odpowiada nauczaniu Kościoła, skoro największym przykazaniem Ewangelii jest przykazaniem miłości. Szczególnym prawem, a także i obowiązkiem Kościoła, nauczającego ustami Soboru bądź Papieża, wydaje się magisterium na temat miłości i jej właściwego znaczenia w życiu ludzkim, w tym wypadku - w życiu małżenstwa i rodziny.

Tak więc Sobór w jednym ze swoich centralnych dokumentów daje nam obszerne pouczenie na temat miłości małżeńskiej, którego tutaj nie będziemy osobno analizować. Można powiedzieć, że stanowi ono jakby tło dla kolejnego pouczenia Pawła VI w encyklice Humanae vitae, które Ojciec św. ma przed oczyma i do którego odwołuje się w najbardziej kluczowych momentach. Jeżeli wolno dokonać na wstępie ogólnego porównania, to wydaje się, że Konstytucja soborowa jest nieco 
bardziej opisowa i bardziej uwydatnia wartości małżeństwa i rodziny, wartości związane z miłością podjętą w duchu Ewangelii, en c yklika natomiast większy kładzie nacisk na powinności, które wartościom tym odpowiadają. Chodzi tutaj - zgodnie $z$ tematem i celem encykliki - przede wszystkim o powinności związane $\mathrm{z}$ przekazywaniem życia w małżeństwie, jednakże nie tylko o nie.

Zaraz też na wstępie wypada podkreślić, że ani Konstytucja soborowa ani też encyklika nie wspomina nigdzie expressis verbis o tradycyjnym ujęciu tzw. hierarchii celów małżeństwa. W ujęciu tym zawsze zdecydowanie podkreślano pierwszeństwo prokreacji (procreatio) przed mutuum adiutorium, widząc za tym drugim znaczeniowy odpowiednik miłości małżeńskiej. Ani Konstytucja soborowa ani też encyklika nie powołuje się na tak ujętą hierarchię celów małżeństwa, ty m bardziej też celów tych wzajemnie nie przeciwstawia. W Gaudium et spes (51) mówi się o uzgadnianiu miłości małżeńskiej $\mathrm{z}$ poszanowaniem życia ludzkiego, w Humanae vitae o nierozerwalnym związku, jaki zachodzi pomiędzy dwoma znaczeniami aktu małżeńskiego. Spróbujemy jednak do tego również problemu dojść poprzez szczegółową analizę.

Dodajmy jeszcze, że zarówno Sobór jako autor Konstytucji pastoralnej, jak też Paweł VI, autor Humanae vitae, ujmują problematykę małżeństwa na gruncie miłości, kierując się świadomością znaczenia takiego właśnie ujęcia dla współczesnego człowieka. „Dają się zauważyć - czytamy w Humanae vitae - pewne zmiany ... w ocenie wartości miłości małżeńskiej oraz znaczenia stosunków małżeńskich dla tej miłości". ${ }^{1}$

\section{TEOLOGIA MIEOŚCI}

Autor encykliki Humanae vitae przede wszystkim stara się o to, aby swej nauce o miłości w małżeństwie zapewnić integralność w znaczeniu teologicznym. I dlatego też rozpoczyna od tego, co o miłości w ogóle, a o miłości małżeńskiej w szczególności, winniśmy myśleć w świetle Objawienia: „Miłość małżeńska najlepiej objawia nam swą prawdziwą naturę i godność dopiero wtedy, gdy rozważamy, że początek swój czerpie ona - jakby $\mathrm{z}$ najwyższego źródła — z Boga, który ,jest Miłością, i ,Ojcem od którego bierze swe imię wszelkie ojcostwo na niebie i na ziemi'". ${ }^{2}$ Rzec można, iż w tym miejscu ukazuje encyklika sam szczyt zagadnienia. Teologiczne ujęcie miłości małżeńskiej musi doprowadzać nas do tego szczytu. Znamienne jest przy tym wyprowadzenie

$1 \mathrm{HV}, 2$ (= Humanae vitae, AAS, 60 (1968) 481-503. Tłumaczenie polskie według „Notificationes e Curia Metropolitana Cracoviensi”, 1-4 (1969) 1-105).

$2 \mathrm{HV}, 8$. 
tego podstawowego sądu o miłości małżeńskiej, sądu teologicznego, z dwóch równocześnie prawd objawionych o B o gu: z prawdy, że jest On Miłością, i z prawdy, że jest Ojcem. Paweł VI pisze, że miłość małżeńska czerpie swój początek z Boga, przez co zdaje się wskazywać na podwójny porządek, mianowicie na porządek sprawczy i wzorczy. Bóg, który jest Miłością i Ojcem, daje początek wszelkiej miłości i ojcostwu w świecie, a w szczególności w życiu małżeńskim, w znaczeniu wzorczym i sprawczym zarazem. Bóg miłość tę kontynuuje samą swoją istotą - właśnie przez to, że sam jest Miłością i że jest Ojcem. Początek wzorczy jest zwłaszcza uwydatniony, gdy chodzi o ojcostwo, przy pomocy słów z listu św. Pawła do Efezjan $(3,15)$. Jednakże słowa Papieża trzeba rozumieć także w znaczeniu sprawczym. Oto bowiem w najbliższym kontekście czytamy o małżeństwie, iż ,...Bóg Stwórca ustanowił je mądrze i opatrznościowo w tym celu, aby urzeczywistniać w ludziach swój plan miłości" ${ }^{3}$. W ten plan miłości małżonkowie wchodzą i sami go urzeczywistniają swoją miłością małżeńską, czytamy bowiem dalej: „Dlatego małżonkowie przez wzajemne oddanie się sobie, im tylko właściwe i wyłączne, dążą do takiej wspólnoty osób, aby doskonaląc się w niej wzajemnie, współpracować równocześnie $\mathrm{z}$ Bogiem w wydawaniu na świat i wychowywaniu nowych ludzi". ${ }^{4}$ Zdanie to posiada kluczowe znaczenie dla dalszych nowych dociekań na temat miłości małżeńskiej w encyklice, tutaj jednakże ze względu na bezpośredni kontekst służy dla potwierdzenia zarówno wzorczości jak i sprawczości Bożej. Można powiedzieć, że Autor encykliki całą ludzką strukturę miłości małżeńskiej i ludzki jej sens przy pomocy tego właśnie zdania osadza mocno na gruncie teologicznym. A ponieważ czyni to na samym początku swego pouczenia o miłości małżeńskiej, każe nam przez to samo jakby stale powracać do tego właśnie gruntu, na którym wszystko, co dalej o niej powie, jest osadzone.

Ażeby dokończyć tego teologicznego ugruntowania, Paweł VI podaje jeszcze jedno zdanie o Sakramencie małżeństwa: „Dla ochrzczonych zaś małżeństwo nabiera godności sakramentalnego znaku łaski, ponieważ wyraża związek Chrystusa z Kościołem". ${ }^{5} \mathrm{~W}$ ten sposób teologia miłości małżeńskiej, chociaż została tylko zwięźle naszkicowana $\mathrm{w}$ encyklice - zawiera wszystkie istotne elementy, które o niej stanowią. Wzorczość i sprawczość Boża oraz sakramentalność małżeństwa, świadczą wystarczająco o tym, że Autor encykliki pragnie nadać swemu pouczeniu o miłości małżeńskiej integralne znaczenie teolo-

3 HV, 8.

4 HV, 8.

$5 \mathrm{HV}, 8$. 
giczne. W całej encyklice chodzi o miłość w tym znaczeniu. Paweł VI odpowiadając na pytania, które stawia współczesny człowiek, na pytania, które sam na początku encykliki bardzo obszernie i wnikliwie zestawił - odpowiada zasadniczo na jedno pytanie: jaka powinna być miłość małżeńska, aby można w niej odnaleźć odwieczny Boży plan miłości? pod jakimi warunkami odzwierciedla ona swój pierwowzór, którym jest Bóg jako Miłość i Bóg jako Ojciec? $\mathrm{Na}$ tym poziomie trzeba rozpatrywać całokształt encykliki oraz zawartej tam nauki o miłości małżeńskiej.

\section{CHARAKTERYSTYKA MIEOSCI MAEŻEŃSKIEJ}

„Gdy się te sprawy widzi we właściwym świetle - pisze dalej Papież - stają się oczywiste charakterystyczne cechy i wymogi miłości małżeńskiej" ", jakby jeszcze raz pragnął zaakcentować porządek wzorczy, na którym opiera swą teologię miłości małżeńskiej. Charakterystyka tejże miłości jako ludzkiej wspólnoty dwojga osób mężczyzny i kobiety, wydaje się w stosunku do wypowiedzi zawartej w Gaudium et spes stosunkowo zwięzła. Paweł VI w pierwszych zaraz słowach podkreśla „cechy i wymogi”, jakby zapowiadał, w jakim kierunku pójdzie jego analiza miłości małżeńskiej, że będzie w niej nie tylko mowa o wartościach, ale także i o powinnościach, które wartościom tym muszą odpowiadać. W przeciwnym razie każde słowo o miłości byłoby pozbawione pełnego realizmu. I istotnie całą swoją charakterystykę miłości małżeńskiej przeprowadza Autor encykliki pod kątem tej integralności etycznej, jaka winna w niej się zawierać.

,Jest to przede wszystkim miłość na wskroś ludzka, a więc zarazem zmysłowa i duchowa" 7 - czytamy z kolei. Papież z całym poczuciem rzeczywistości mówi o miłości małżeńskiej jako o „ludzkiej”. Stanowi o tym równoczesny udział zmysłowości i duchowości w kształtowaniu się miłości małżeńskiej. Jednakże miłość ta, dlatego właśnie że jest ludzka, stawia małżonkom wyraźne wymagania: „Toteż nie chodzi tu tylko o zwykły impuls popędu lub uczuć - czytamy dalej ${ }^{8}$ - ale także, a nawet przede wszystkim, o akt wolnej woli, zmierzający do tego, aby miłość ta w radościach i trudach codziennego życia nie tylko trwała, lecz jeszcze wzrastała, tak ażeby małżonkowie stawali się niejako jednym sercem i jedną duszą, i razem osiągali swą ludzką doskonałość". To wszystko dopiero stanowi i świadczy o tym, że miłość małżeńska jest rzeczywiście „ludzka”. Takie obopólne zaangażowanie duchowości i zmysłowości, a także - jakież to ma znaczenie w tym wypadku - uczu- 
ciowości, serca, nadaje miłości małżeńskiej prawdziwie ludzki wyraz: i kształt. $\mathrm{Na}$ gruncie tej cechy charakterystycznej miłości małżonków, że jest ona „ludzka”, Autor encykliki widzi i wskazuje zarazem owo wymaganie ws pólnego dążenia do ludzkiej doskonałości, jaka się stąd wyłania.

Podobnie, gdy chodzi o drugą charakterystyczną cechę miłości małżeńskiej. Paweł VI uczy, iż winna to być miłość pełna, a gdy chodzi o miłość pełną - czytamy dalej — „to znaczy o tę szczególną formę przyjaźni osób, poprzez którą małżonkowie wielkodusznie dzielą między sobą wszystko bez niesprawiedliwych wyjątków i egoistycznych rachub. Kto prawdziwie kocha swego współmałżonka, nie kocha go tylko ze względu na to, co od niego otrzymuje, ale dla niego samego, szczęśliwy, że może go wzbogacić darem z samego siebie" ${ }^{9}$. Oto, jak Kościół rozumie w oparciu o doświadczenie ludzkie oraz o cały humanistyczny, personalistyczny i etyczny dorobek ludzkiej refleksji ową pełnię miłości. Niesie on $\mathrm{z}$ sobą nie tylko jednostronne uprawnienia, ale szczególne wymagania. Są to te wy magania, jakie ludziom stawia prawdziwa przyjaźń, biorąc pod uwagę tę szczególną jej formę, o jaką chodzi w małżeństwie - tę szczególną miarę oddania siebie, jakie w nim się zawiera i urzeczywistnia, domagając się, rzecz jasna, stosownej wzajemności. Mi a r ą, do jakiej tutaj trzeba się stale odwoływać, jest ów dar z osoby. On stoi u podstawy wszystkiego, co małżonkowie „dzielą między sobą", on stanowi o głębi ich wspólnoty i zjednoczenia. Wzajemny dar z osoby, który w małżeństwie jest faktem, musi równocześnie stawać się - niejako na gruncie tego faktu - wymaganiem i normą czynów, ażeby miłość małżeńska prawdziwie była pełna.

Paweł VI charakteryzuje ją z kolei jako wierną i wyłączną. „Prócz tego miłość małżeńska - czytamy dalej - jest wierna i w y$\mathfrak{l a ̨ c z n a}$ aż do końca życia; to znaczy jest taka, jak ją rozumieli małżonkowie w tym dniu, w którym wolni i w pełni świadomi wiązali się węzłem małżeńskim" ${ }^{10}$. Autor encykliki wiąże wierność i wyłączność jako cechy charakterystyczne miłości małżeńskiej z nierozerwalnością samego małżeństwa, jak to wynika $\mathrm{z}$ dalszych słów tekstu. Jednakże cechy te pozostają $\mathrm{w}$ głębokim związku $\mathrm{z}$ przedstawioną uprzednio cechą pełni miłości i z jej personalistyczną interpretacją. Czytamy więc: „Choćby ta wierność małżeńska napotykała niekiedy na trudności, to jednak nikomu nie wolno uważać jej za niemożliwą, wręcz przeciwnie, jest zawsze szlachetna i pełna zasług. Przykłady tak licznych w ciągu

s HV, 9.

9 HV, 9.

$10 \mathrm{HV}, 9$. 
wieków małżonków dowodzą nie tylko tego, że wierność jest zgodna $z$ naturą małżeństwa, lecz ponadto, że stanowi ona niejako źródło, z którego płynie głębokie i trwałe szczęście”. Tu właśnie, w tych ostatnich słowach, wierność i wyłączność miłości małżeńskiej ukazuje się jakby aspektem owej pełni, o której była mowa uprzednio - p ełn i, k tór a wynika ze wzajemnego daru osób. Ów wzajemny dar $\mathrm{w}$ tej postaci, jak to zachodzi w małżeństwie, zakłada wyłączność, a więc i wierność wzajemną. I na tej właśnie zasadzie owa wyłączność i wierność staje się źródłem szczęścia. Szczęście tłumaczy się zarówno jakością daru jak i jego trwałością.

„Jest to wreszcie miłość płodna” 11 — pisze dalej Paweł VI - kończąc przez wskazanie tej cechy swą charakterystykę miłości małżeńskiej: „...miłość płodna - czytamy - która nie wyczerpuje się we wspólnocie małżonków, ale zmierza również ku swemu przedłużeniu i wzbudzeniu nowego życia”. Następuje cytat z Gaudium et spes: „,...Dzieci są też najcenniejszym darem małżeństwa i samym rodzicom przynoszą najwięcej dobra" ${ }^{12}$. W tym miejscu rozpoczną się szczegółowe rozważania i stwierdzenia na temat owych wymogów i powinności, jakie stawia miłość małżeńska ze względu na tę swoją cechę charakterystyczną i wyjątkową, że jest płodna - i my też za tym tokiem rozważań Pawła VI podążymy. Przed tym jednakże należy raz jeszcze uwydatnić znaczenie, jakie nadaje on miłości małżeńskiej poprzez zestawienie głównych jej ludzkich cech. W każdej z ty ch cech wartość spotyka się z powinności ą — rzec można: wielka wartość z ważką powinnością - a wszystkie stanowią o miłości. Ojciec św. uczy miłości małżeńskiej z całą powagą, jakiej temat ten się domaga. Poucza o niej, wskazując na wartość i powinność równocześnie. W ten sposób pouczenie encykliki Humanae vitae, stosownie do posłannictwa Papieża i jego urzędu nabiera znaczenia etycznego. Jest to a u tentyczne nauczanie moralności. Troska o integralność w znaczeniu etycznym idzie $\mathrm{w}$ parze $\mathrm{z}$ troską o integralność teologiczną dokumentu, jak to uprzednio stwierdzono.

\section{PERSONALISTYCZNE UJĘCIE MIEOSCI MAEŻEŃSKIEJ}

Paweł VI przechodzi do zasadniczego tematu swej encykliki, do tego tematu, który Konstytucja Gaudium et spes określiła jako „uzgadnianie miłości małźénskiej z poszanowaniem życia ludzkiego" 13. Sobór,

\footnotetext{
$11 \mathrm{HV}, 9$.

12 GS, 50.

13 GS, 51.
} 
uchwalając Konstytucję liczył się z tym, że Papież w tej właśnie sprawie wypowie się w sposób bardziej szczegółowy. Encyklika Humanae vitae czyni zadość temu właśnie oczekiwaniu poprzez autorytatywne stanowisko $\mathrm{w}$ sprawie świadomego rodzicielstwa $\mathrm{z}$ jednej, a antykoncepcji z drugiej strony. Jeżeli mamy przedstawić tutaj całokształt nauki Pawła VI o miłości małżeńskiej, musimy zapoznać się z tym stanowikiem - nie tyle dla niego samego, ile właśnie ze względu na to, że stanowi ono wyraźną implikację pouczenia o miłości małżeńskiej, zarówno w aspekcie jej teologicznego jak i etycznego znaczenia, o czym dotąd była mowa. Metodolog w zakresie etyki i teologii moralnej winien by przestudiować tę implikację pod kątem procesu wyprowadzania oraz uzasadniania norm szczegółowych — chodzi właśnie o normy $w$ stosunku do świadomego rodzicielstwa $z$ jednej, a antykoncepcji $\mathrm{z}$ drugiej strony - w jakiej mierze ów proces zawiera się $\mathrm{w}$ encyklice. Tę pracę trzeba pozostawić metodologowi. W niniejszej natomiast rozprawie nie można pominąć stanowiska Pawła VI wobec świadomego rodzicielstwa i antykoncepcji, gdyż stanowisko to wydaje się gruntownie zakorzenione w pouczeniu o miłości - co zresztą niech wykażą teksty.

Rzecz jasna, że w celu wykazania owych implikacji musimy w ślad za wywodem encykliki, przejść do analizy konkretnego aktu małżeńskiego i wniknąć w jego wewnętrzny ład. Akt małżeński jest stosunkiem - i to nie stosunkiem w znaczeniu tylko „seksualnym", ale w znaczeniu ontologicznym. Jak każdy stosunek relatio - urzeczywistnia się on w podwójnym aspekcie: urzeczywistnia się w jednej z osób „względem" drugiej, a zarazem urzeczywistnia się „,pomiędzy nimi”. Stosunki małżeńskie, tak jak i cała miłość małżeńska podlegają kwalifikacji etyczno-teologicznej, są to bowiem prawdziwe czyny ludzkie, w których wymienione uprzednio cechy miłości nie tylko sama płodność - w szczególny sposób domagają się potwierdzenia. Wypada bardzo gruntownie przeanalizować odnośne fragmenty tekstu encykliki, gdyż wyłania się z nich jeszcze głębszy kształt zawartejtam nauki o miłości. Można powiedzieć, że chodzi tutaj o samą realną egzystencję miłości małżeńskiej, która zawsze istnieje „w” osobach - mężu i żonie i istnieje ,pomiędzy" nimi, zgodnie ze swą dwoistą naturą: cnoty (czy też wewnętrznej postawy względem drugiej osoby) i relacji. Miłość zawsze jest stosunkiem osób. Chodzi o to, pod jakimi warunkami stosunek małżeński spełnia wymogi miłości. Paweł VI odpowiada na to pytanie, przypominając niezmienną naukę Kościoła o podwójnej funkcji, jaką oznacza i spełnia akt małżeński - i o nierozerwalnym związku obu tych funkcji. 
Ów nierozerwalny związek jest - jak czytamy w encyklice ${ }^{14}$ ustanowiony przez Boga, a człowiekowi nie wolno go samowolnie zrywać. Chodzi tutaj o związek „między dwojakim znaczeniem tkwiącym w stosunku małżeńskim: między oznaczaniem jedności i oznaczaniem rodzicielstwa". Jest to ogromnie znamienny tekst. Można powiedzieć, że Paweł VI przeprowadził $\mathrm{w}$ nim tradycyjną i niezmienną naukę moralną Kościoła przez pryzmat tych wymagań, jakie - pod względem przede wszystkim formalnym - stawia współczesna psychologia i nauka o człowieku nawiązując przy tym do gruntownej ontologii miłości. Można powiedzieć więcej - że Pawel VI tę ontologię miłości $w$ pełni ujawnił, opierając na niej w zasadniczej mierze zajęte w encyklice stanowisko wobec świadomego rodzicielstwa oraz antykoncepcji.

Kiedy bowiem Autor encykliki odwołuje się do znaczenia tkwiącego w akcie małżeńskim, wówczas stawia całe zagadnienie nie tylko i nie tyle na gruncie samej natury tego aktu, ile także na gruncie ludzkiej świadomości, na gruncie tego zrozumienia, jakie musi mu odpowiadać po stronie zarówno mężczyzny jak i kobiety — osób ten akt spełniających. Można odkryć w tej części tekstu encykliki bardzo z n a mienne przejście od tego, co niektórzy gotowi sązwać, „teologią natury”, do ,t e ologi os oby”. Kiedy mianowicie mowa o dwojakim znaczeniu tkwiącym w stosunku małżeńskim, wówczas wydaje się to odpowiadać pojęciu natury: w naturze aktu tkwi wyraz miłości oraz możliwość płodności. Jednakże Autor Humanae vitae nie zadawala się takim sformułowaniem. Pisze natomiast $\mathrm{w}$ tym wypadku o znaczeniu, zakładając zrozumienie owej natury aktu ze strony człowieka. Więcej jeszcze: pisze nie tylko o znaczeniu aktu małżeńskiego jako wyniku zrozumienia jego natury, a le także o oznaczaniu i o $\mathrm{znaku}$. Osobowy podmiot aktu małżeńskiego - mężczyzna czy kobieta - nie tylko jest świadomy jego znaczenia, ale dopełniając tego aktu, to właśnie tylko a nie inne znaczenie, może i powinien mu nadać: to tylko, a nie co innego, może i powinien nim oznaczyć. Stosunek małàeński został pojęty w encyklice jako znak. Czytamy: „Albowiem stosunek małżeński $z$ najgłębszej swojej istoty, łącząc najściślejszą więzią męża i żonę, jednocześnie czyni ich zdolnymi do zrodzenia nowego życia, zgodnie $\mathrm{z}$ prawami zawartymi $\mathrm{w}$ samej naturze mężczyzny i kobiety. Jeżeli zatem zostaną zachowane te dwa istotne elementy stosunku małżeńskiego, a więc oznaczenie jedności i rodzicielstwa, to wtedy zatrzymuje on w pełni swoje znaczenie wzajemnej i prawdziwej miłości oraz swoje odniesienie do bardzo wzniosłego zadania, do którego człowiek zostaje powołany - mianowicie do rodzicielstwa. I Papież dodaje:

$14 \mathrm{HV}, 12$. 
Sądzimy, że ludzie naszej epoki są szczególnie przygotowani do zrozumienia, jak bardzo ta nauka jest zgodna z ludzkim rozumem" 15. Można w tym ostatnim zdaniu widzieć równoważnik odwołania się do prawa natury, co znowu jest odrębnym zagadnieniem.

Dla nas cały ten passus jest ważny $\mathrm{ze}$ względu na analizę miłości małżeńskiej, której aspekt teologiczny i etyczny został w sposób ogólny nakreślony uprzednio. Tutaj, jak powiedziano, przechodzimy do konkretnej egzystencji miłości małżeńskiej, która zawsze istnieje jako relacja czyli stosunek w osobach i między osobami. Akt małżeński nie tyle jest potwierdzeniem, ile powinien być jej potwierdzeniem. Egzystencja miłości zawiera się pomiędzy tym ,jest" a tym „powinien być”. Nie można jej po prostu utożsamiać z aktem małżeńskim, ale trzeba szukać w osobach, w ich świadomości, wyborze, decyzji i odpowiedzialności moralnej. Mężczyzna i kobieta mają świadomość znaczenia aktu małżeńskiego. Co więcej - spełniając go, mogą i powinni nim oznaczyć właśnie to, co on sam w sobie znaczy. Znaczy zaś i szczególne zjednoczenie osób i zarazem możliwość (nie konieczność!) płodności, prokreacji. Jeśli działając wspólnie, chcą nim to właśnie oznaczyć, wówczas działanie ich jest wewnętrznie prawdziwe, jest wolne od zafałszowania. W intencjonalnej sferze znaczeń nie zafałszowują tego znaczenia, jakie ich wspólne działanie - a zarazem działanie każdego z nich w tej wspólnocie działań - posiada w sferze realnej, posiada jako ściśle określona rzeczywistość aktu máłżeńskiego.

Wydaje się, że ten zwłaszcza fragment encykliki jest bardzo ważny dla uwydatnienia personalistycznego charakteru miłości małżeńskiej, przy czym chodzi tutaj, jak widać, o personalizm integralny, o personalizm w znaczeniu etycznym. W bardziej tradycyjnym ujęciu mówiono by o zgodności działania $z$ rozumem - i Autor Humanae vitae również to mówi. Nie poprzestaje jednakże na abstrakcyjnym stwierdzeniu tej

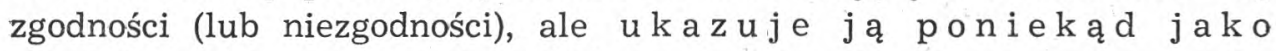
przézycie znaczenia, które to przé̇ycie zawiera się w całej osnowie ludzkiegodziałania małżonków. Gdy mowa $\mathrm{w}$ tekście encykliki o znaczeniu i oznaczaniu (czy też znaku) wówczas Autor jej chce przez to wyrazić, czym dla miłości jest wewnętrzna, a zarazem obiektywna prawda działań składających się na akt małżeński. Od tej prawdy zależy, czy panuje w nim wewnętrzny ład czy też ładu tego brak. Od tej prawdy zależy, czy akt małżeński jest aktem miłości w znaczeniu integralnym czy też nim nie jest.

\footnotetext{
15 HV, 12.

16 HV, 16.
} 
Jeżeli nauka Kościoła poprzez Humanae vitae ,uznaje za dozwolone uwzględnianie przez małżonków okresów niepłodności" ${ }^{16}$ (czyli to co nazywa się etyczną regulacją poczęć), natomiast „potępia jako zawsze zabronione stosowanie środków bezpośrednio zapobiegających poczęciu" ${ }^{17}$ (czyli to, co właściwie rozumiemy pod słowem ,,antykoncepcja”) czyni to $\mathrm{w}$ tym przeświadczeniu, iż ta pierwsza nie narusza zawartego w akcie małżeńskim porządku znaczeń, druga natomiast narusza. Pierwsza tzn. etyczna regulacja poczęć, nie zakłóca prawdy ludzkich działań składających się na akt małżeński, podczas gdy druga, tj. antykoncepcja, nie może jej nie zakłócać. W obrębie etycznej regulacji poczęć małżonkowie mogą swoim działaniem w akcie małżeńskim oznaczyć to, co te działania z istoty swojej znacza, podczas gdy antykoncepcja to uniemożliwia. Dlatego też Papież dodaje: „W rzeczywistości między tymi dwoma sposobami postępowania zachodzi istotna różnica" ${ }^{18}$.

Nie chodzi nam w tej chwili o etyczną regulację poczęć czy też o antykoncepcję samą w sobie. Chodzi tylko o stwierdzenie, że w kontekście encykliki Humanae vitae problem ten stanowi implikację zawartej tam nauki o miłości małżeńskiej. Implikacja ta staje się bardziej przejrzysta na gruncie personalistycznego ujęcia tej miłości, co tutaj staraliśmy się wykazać.

\section{POTRZEBA INTEGRACJI}

Personalizm ten pozwala nam łatwiej nawiązać łączność pomiędzy znaczeniem etycznym a znaczeniem psychologicznym miłości małżeńskiej, a zwłaszcza pomiędzy tymi dwoma znaczeniami, jakie niesie w sobie sam akt małżeński. Wydaje się bowiem, że encyklika Humanae vitae respektuje oba te znaczenia i nie zaciera pomiędzy nimi granicy. Jeżeli współczesne poglądy na „wartość miłości małżeńskiej oraz znaczenie stosunków małżeńskich dla tej miłości" ${ }^{19}$ zdają się być nacechowane jednostronnym psychologizmem, to encyklika nie reaguje na nie jednostronnym moralizmem. W pewnym sensie wskazały już na to dotychczas przytoczone teksty encykliki oraz ich analiza. Pogląd, że akt małżeński winien służyć zjednoczeniu małżonków, ich jedności, że nie sama tylko celowość prokreacyjna jest jego etycznym uzasadnieniem, wskazuje dostatecznie na to, jak zawarte w encyklice nauczanie moralności jest jednakże wolne od jednostronnego moralizmu. $\mathrm{Z}$ pewnością też to miejsce, jakie encyklika pozostawia dla

\footnotetext{
$17 \mathrm{HV}, 16$.

$18 \mathrm{HV}, 16$.

19 HV, 2.
} 
psychologii miłości małżeńskiej - choć się oczywiście w nią nie zagł̨bia — jest owocem owej integralnej wizji człowieka ${ }^{20}$, którą Paweł VI stale ma przed oczyma, odwołując się do niej na samym początku części doktrynalnej encykliki. Właśnie też to nas umacnia w przekonaniu, że całe ujęcie miłości małżeńskiej w Humanae vitae jest zasadniczo personalistyczne, co uprzednio już staraliśmy się wykazać. Na tym właśnie gruncie tłumaczy się stosunek pomiędzy psychologicznym a etycznym znaczeniem miłości, którego w tekstach encykliki możemy się doczytać.

I tak np. poruszywszy problem wewnętrznego ładu, jaki powinien panować w akcie małżeńskim, Paweł VI stwierdza, że „współżycie płciowe narzucone współmałżonkowi bez liczenia się z jego stanem oraz z jego uzasadnionymi życzeniami, nie jest prawdziwym aktem miłości i dlatego sprzeciwia się temu, czego słusznie domaga się ład moralny we wzajemnej więzi między małżonkami" 21. Papież stwierdza, że lad moralny domaga się miłości, oraz wyraźnie wskazuje na to, że akt małżeński może nie być aktem miłości. Wynika stąd konieczność rozróżnienia i w zakresie poszczególnych aktów małżeńskich i z pewnością też w zakresie całych postaw - tego, co jest miłością, od tego co nią nie jest. Może znajduje tutaj pewne uzasadnienie powiedzenie o dobrej i ,złej miłości”.

Autor encykliki kontynuuje w taki sposób swoją myśl: „Podobnie, jeżeli się sprawę dobrze rozważy, trzeba przyznać, że taki wzajemny akt miłości dokonany $\mathrm{z}$ uszczerbkiem dla zdolności przekazywania życia - którą Bóg Stwórca wszechrzeczy związał z tym aktem specjalnymi prawami - pozostaje w sprzeczności zarówno z planem Bożym, według którego małżeństwo zostało ustanowione, jak z Wolą Pierwszego Twórcy życia. Jeżeli więc ktoś korzysta z daru Bożego, pozbawiając go choćby tylko częściowo, właściwego mu znaczenia i celowości, działa wbrew naturze tak mężczyzny jak i kobiety, a także wbrew głębokiemu ich zespoleniu" ${ }^{22}$. Tekst niezwykle znamienny. Autor encykliki mówi w nim równocześnie o naturze i celowości aktu małżeńskiego, i równocześnie też o jego integralnym znaczeniu. Wydaje się, że bierze pod uwagę nie tylko obiektywne znaczenie aktu, tkwiące $w$ jego naturze, ale także poniekąd i subiektywne, przeżyciowe jego znaczenie od strony małżonków. Aspekt etyczny i aspekt psychologiczny zarysowują się w tym ujęciu jako dwie treści, które na gruncie jednego i tego samego podmiotu - a raczej podmiotów: mężczyzny i kobiety - domagają się wzajemnej integracji.

\footnotetext{
20 HV, 7.

21 HV, 13.

22 HV, 13.
} 
Autor encykliki pisze 0 ,,akcie wzajemnej miłości dokonanym z uszczerbkiem dla zdolności przekazywania życia" jako o akcie miłości jakby nie chciał zaprzeczać, że w akcie tym zasadniczo chce się zawsze wyrażać i przejawiać miłość małżeńska, że odpowiada to psychologicznej potrzebie tej miłości. Równocześnie jednak z punktu widzenia tejże miłości, nawet $\mathrm{w}$ aspekcie jej rzeczywistego przeżycia, czynne naruszenie „znaczenia i celowości”, która odpowiada planowi Stwórcy, musi działać „wbrew głębokiemu zespoleniu” małżoḱw. Rzec można, tłumacząc myśl tutaj zawartą, że akt małżeński nie p osiada wówczas wartości prawdziwego zjednocznia o s ó b. W naruszeniu wewnętrznego ładu aktu małżeńskiego w aspekcie „zdolności przekazywania życia” Paweł VI widzi równocześnie a nawet jakby jeszcze głębiej idące - naruszenie samej prawdy osobowej miłości. Dla tej prawdy nie jest obojętny również sam sposób współżycia małżeńskiego.

I dlatego też Paweł VI, w innym miejscu encykliki, pisząc o małżonkach, którzy zdobywają się w swym współżyciu na okresową wstrzemięźliwość stwierdza: „Postępując w ten sposób, dają oni świadectwo prawdzie i w pełni uczciwej miłości" ${ }^{23}$. Widać tutaj, że pojęcie miłości domaga się jakby wyraźnego ujednoznacznienia od strony etyki (,w pełni uczciwa miłość"), gdyż psychologiczne jego znaczenie jeszcze nie przesądza o tym, czy mamy do czynienia z „uczciwą" czy też „nieuczciwą miłością". Podobnie, jak akt małżeński sam z siebie jeszcze nie przesądza, czy jest prawdziwym aktem miłości, czy też nim nie jest. Aby nim był, musi zachodzić w nim integracja wartości psychologicznej poprzez wartość etyczną. Integracja ta sięga głębiej jeszcze, sięga $\mathrm{w}$ teologię miłości „kto korzysta z daru miłości małżeńskiej z poszanowaniem praw przekazywania życia, ten uznaje, że nie jest panem źródeł życia, ale raczej sługą planu ustalonego przez Stwórcę" ${ }^{24}$. W teologii miłości, nakreślonej na początku encykliki, Bóg jako miłość i Bóg jako Ojciec, nadaje ostateczne, najwyższe znaczenie miłości małżeńskiej i poszczególnym jej aktom. Ta teologia miłości przenika, jak powiedziano, całą zawartą $\mathrm{w}$ encyklice Humanae vitae naukę o miłości małżeńskiej.

Jest to autentyczna nauka Ewangelii. Paweł VI podkreśla, że Kościół nigdy nie zaniedba nałożonego mu obowiązku ,głoszenia z pokorą i stanowczością całego prawa moralnego, tak naturalnego jak i ewange-licznego" 25. Prawo ewangeliczne czyli przykazanie miłości jest nie tylko pociągające, ale i trudne, co przejawia się między innymi w nauce o mi- 
łości małżeńskiej. Określenie jej prawdziwego znaczenia, a zwłaszcza ścisłe i odpowiedzialne pouczenie na temat realizacji tej miłości w aktach małżeńskich, często natrafia na sprzeciw. Sprzeciw ten jest pośrednim sprawdzianem prawdy zawartej w samym pouczeniu, które nie ma znaczenia tylko teoretycznego czy abstrakcyjnego, ale jest skierowane w stronę życia i postępowania ludzkiegó Od tej strony owa miłość w swej właściwej ewangelicznej treści musi być przez ludzi - w tym wypadku przez małżonków - osiągana jako dobro także i trudne. „Nie ulega żadnej wątpliwości — czytamy w Humanae vitae - że rozumne i wolne kierowanie popędami wymaga ascezy, ażeby znaki miłości, właściwe dla życia małżeńskiego, zgodne były z etycznym porządkiem, co konieczne jest zwłaszcza dla zachowania okresowej wstrzemięźliwości. Jednakże to opanowanie, w którym przejawia się czystość małżeńska, nie tylko nie przynosi szkody miłości małżeńskiej, lecz wyposaża ją w nowe ludzkie wartości. Wymaga ono wprawdzie stałego wysiłku, ale dzięki jego dobroczynnemu wpływowi małżonkowie rozwijają w sposób pełny swoją osobowość, wzbogacając się o wartości duchowe" 26 .

Praktycznym potwierdzeniem miłości małżeńskiej jakomiłości odpowiadającejnajwiększemu przykazaniu Ewangeli i jest właśnie to, że wartości są w niej małżonkom niejako zadane, i że muszą być osiągane na drodze pewnego wysiłku ascetycznego. $\mathrm{Na}$ tym właśnie polega praktyczna, egzystencjalna i doświadczalna zarazem, integracja tej miłości. Do całokształtu ascezy miłości należy również i wstrzemięźliwość, a czystość małżeńska stanowi wówczas jakby czynnik integrujący. Na tej też drodze miłość małżeńska staje się również owocem Łaski, ,mocą której człowiek staje się nowym stworzeniem zdolnym $\mathrm{w}$ miłości i prawdziwej wolności odpowiedzieć na boski plan Stworzyciela i Zbawcy oraz odczuć słodycz Chrystusowego jarzma" ${ }^{27}$. W Łasce tej ujawnia się nadprzyrodzona moc Sakramentu małżeństwa, który małżonków „niejako konsekruje, by wiernie wypełniali swe obowiązki, by swe powołanie doprowadzili do właściwej mu doskonałości, oraz by dawali, jak na nich przystało, chrześcijańskie świadectwo wobec świata" 28.

\section{ZNACZENIE DLA MORALISTÓW I DUSZPASTERZY}

Czas na pewną reasumpcję treści dokonanych tutaj analiz, które miały na celu gruntowniejsze odczytanie zawartej w Humanae vitae nauki o miłości. Z uwagi na egzegetyczny poniekąd charakter niniejszego arty-

$28 \mathrm{HV}, 25$. 
kułu trzeba stwierdzić, że nauka ta kształtowała się niejako już ,po drodze", w czasie dokonywania samych analiz oraz w związku z nimi. Przy końcu wystarczy może dodać, że Autor encykliki swoje magisterialne pouczenie o miłości małżeńskiej-a więc autorytatywne nauczanie moralności chrześcijańskiej (o nastawieniu również praktyczno-pastoralnym) - ujmuje niejako z dwóch stron. $\mathrm{Z}$ jednej strony daje ogólny pogląd na znaczenie miłości małżeńskiej, pogląd o charakterze teologicznym i etycznym zarazem. Z drugiej zaś strony uczy o miłości małżeńskiej poprzez gruntowną analizę aktu małżeńskiego. To dwustronne ujęcie zagadnienia pomaga nam głębiej wniknąć w samą rzeczywistość miłości, która właśnie w poszczególnych aktach, w całym ludzkim działaniu małżonków, w sposób zaś szczególny w samym akcie małżenskim - i potwierdza się i zarazem pełniej ujawnia swoją istotę. Otwiera się tutaj szerokie pole dla ujęć specjalistycznych.

Nauka Pawła VI o miłości małżeńskiej zawarta w encyklice Humanae vitae, wskazuje na to, że całą problematykę chrześcijańskiej moralności małżeńskiej musimy mocniej opierać na samej ontologii malżeństwa. Tradycyjny schemat, wysuwający w nauczaniu o małżeństwie przytoczoną na początku hierarchię jego celów, nie został - ani w G a udium et spes ani w Humanae vitae - zakwestionowany. Dokumenty te wskazują natomiast zarówno teologom jak i duszpasterzom potrzebę zakorzenienia wyrażonej tym schematem teologii małżeństwa w jego rzetelnej ontologii. Gruntowna ontologia małżeństwa, czyli owa integralna wizja człowieka, wizja mężczyzny i kobiety jako osób, najlepiej służy prawidłowej koordynacji celów małżeństwa. Służy ona także wyprowadzeniu oraz uzasadnieniu norm, które w małżeństwie odnoszą się zawsze do osób. Pod tym względem encyklika Humanae vitae, a zwłaszcza zawarte w niej pouczenie o miłości jest bardzo znamienne. Można powiedzieć, że wskazuje ono na możliwość - a nawet konieczność - pewnego przekształcenia optyki zagadnienia, przy zachowaniu - a nawet dla zachow a n i a - ścisłej tożsamości doktryny.

$\mathrm{W}$ ten sposób został też zrealizowany w encyklice Humanae vitae wysunięty na Soborze postulat dowartościowania miłości małżeńskiej, zostało także uściślone jej znaczenie w nauce moralnej Kościoła na temat małżeństwa. 


\section{R E S U M E}

\section{DOCTRINE DE L'ENCYCLIQUE ,HUMANAE VITAE” SUR L'AMOUR HUMAIN} (analyse du texte)

L'encyclique Humanae vitae contient un enseignement riche sur l'amour humain. Grâce à ses attaches avec le plus grand des commendements évangéliques, ce sujet correspond exactement à l'enseignement de l'Eglise.

\section{THEOLOGIE DE L'AMOUR}

Dans son enseignement, Paul VI souligne que c'est de Dieu que l'amour humain prend son origine. En son appréciation théologique, le Pape fait dériver sa thèse fondamentale de deux vérités révélées sur Dieu: qu'll est l'amour, et qu'll est le Père. En insistant ainsi sur l'origine réelle de l'amour en question, Paul VI indique un double ordre y existant: celui causal et celui exemplaire. Puis, soulignant le rôle fondamental du sacrement de mariage, il supplée ainsi les principes théologiques de l'amour humain. De cette manière, le Pape forme les bases de la réponse à une question importante: quel devrait être l'amour conjugal pour correspondre au plan éternel de Dieu sur l'amour? Dans quelles conditions refléterait-il son prototype, donc: Dieu-amour et Dieu-père?

\section{CARACTERISTIQUE DE L'AMOUR HUMAIN}

Une caractéristique de l'amour conjugal ainsi faite, Paul VI détermine, ensuite, formellement ,ses caractères et ses exigences”, en attirant l'attention sur ses valeurs, mais aussi sur les devoirs qui devraient correspondre aux valeurs en question. Déterminant l'amour conjugal comme ,humain”, donc: ,sensuel et spirituel" à la fois le Pape indique, en même temps, des exigences d'une aspiration commune de deux époux à une perfection humaine. Il place l'amour total sur le plan des devoirs présentés aux hommes par une amitié véritable. Un don mutuel de leurs personnes propres est une mesure de ces exigences. D'autres traits successifs de l'amour conjugal: sa fidélité et son exclusivisme résultent du don réciproque de deux époux. Une fécondité, dernier trait caractéristique de l'amour en question, constitue un point de départ pour des considérations et des thèses sur les exigences que l'amour conjugal pose, justement de ce tître.

\section{L'AMOUR CONJUGAL DU POINT DE VUE PERSONNALISTE}

Le Pape déduit, ensuite, les normes particulières à l'égard de la maternité consciente d'une part et, envers l'anticonception de l'autre. Il les motive, en passant à une anlyse de l'acte conjugal concret et en pénétrant son ordre intérieur. En insistant sur le caractère personnaliste de l'amour conjugal, Paul VI donne une réponse au problème des conditions, où l'acte conjugal remplirait les exigences de l'amour mentionné. Il met, aussi, en relief, l'union indissoluble existant entre la désignation de l'unité et celle de la paternité. Ainsi, il place le problème moins sur le plan de la nature-même de l'acte conjugal que sur celui d'une compréhension qui, de la part des personnes réalisant l'acte mentionné, devrait lui correspondre. De cette manière, il est possible d'apercevoir, dans l'encyclique, un passage caractéristique, de ce que certains théologiens nomment „une théologie de la nature" à ,une théologie de la personne”. 
Le problème d'une régulation éthique des conceptions, comme aussi celui de l'anticonception, constituent une implication d'enseignement sur l'amour conjugal dans le contexte de l'encyclique Humanae vitae.

\section{BESOIN D'INTEGRATION}

Une perspective personnaliste de l'amour conjugal y présentée, permet de préciser une connexité existant entre la signification éthique et celle psychologique de l'amour humain.

Ainsi, une distinction essentielle entre ce qu'est l'amour et, ce qui n'en est pas, (dans le domaine des actes conjugaux particuliers, comme aussi dans celui des attitudes humaines), a été précisée formellement. Paul VI lie ses exigences, à l'égard de l'amour authentique conjugal, avec l'enseignement de l'Evangile, en soulignant que les valeurs contenues dans cet amour, doivent être atteintes par l'effort d'ascèse et aide de la grâce.

\section{SIGNIFICATION DE HUMANAE VITAE POUR MORALISTES ET PRETRES}

En somme, l'enseignement de Paul VI sur l'amour conjugal précise ses directives de deux points de vues. D'une part, il donne une conception générale de signification de l'amour en question, dans une perspective à la fois théologique et éthique. De l'autre, grâce à une analyse profonde de l'acte conjugal, il instruit de l'amour conjugal, lui-même.

L'encyclique Humanae vitae montre aux théologiens comme aux prêtres, la nécessité d'enraciner la théologie de mariage dans une ontologie profonde de celui-ci. L'ontologie mentionnée ou une vision intégrale de l'homme (ici: celle de deux époux en tant que personnes humaines) s'applique le mieux à déduire et à prouver les normes éthiques qui doivent diriger une vie conjugale. Tout cela permet à une sorte de transformation de l'optique à l'égard de l'enseignement catholique sur le mariage et sur ses buts, la conservation d'identité doctrinale stricte y comprise. 